\title{
Community Participation of Yogyakarta as Climate Resilience City (CRC)
}

\author{
Heribertus Jaka Triyana*; Endah Rantau Itasari ${ }^{\star \star}$ \\ ^ Faculty of Law, Gadjah Mada University \\ jaka.triyana@mail.ugm.ac.id

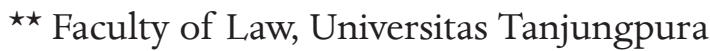 \\ endah.rantau.itasari@hukum.untan.ac.id
}

\begin{abstract}
Community has played central roles for initiatives of the Local Resilience Action Plan (LRAP) toward Yogyakarta as Resilience Climate City (CRC) since 2012. This paper aims to find out relevance of community participation using the Catholic Church and Islamic Youth organizations participation as the model for dissemination and education on CRC as part of global agenda for achievement of the sustainable development goals. This paper is a empirical legal research conducted through an extensive and in-depth analysis of relevance legal data, i.e. primary and secondary data. At the end, they were completed through in depth analysis of legal logic to sustain their correlation and attribution to the said indicators of availibility, accessibility, adaptability and acceptability based on localities' contexts and perspectives in Yogyakarta city. This paper reveals two conclusions. First, Catholic Churches and Islamic Youth Organizations in Yogyakarta city have played role to educate and to disseminate CRC through its internal Church guidance of the arch Bishop of Semarang manifestation 2035 and intended speech from Islamic leaders. Secondly, internal driven motivation is one of fundamental Christian values has been effective to continuously manage house hold wastes, increase green Catholic life style, and to map potential climate vulnerabilities.
\end{abstract}

Keywords: local resilience; action plan; climate reslience city; Catholic 
Church participation.

\section{A. Introduction}

Yogyakarta City covers 3.250 hectares or $32.5 \mathrm{~km} 2$ and it is located in the Special Province of Yogyakarta (Daerah Istimewa Yogyakarta). It is very well known for its culture and heritage tourism and its label of city for education. It has two imminent geographical vulnerabilities, i.e. natural and human activities. ${ }^{1}$ The former refers to its line of ring of fire where Mount Merapi erupts regularly and its active tectonic slope where earthquake shakes this City periodically. For example, the 2010 eruption claimed 277 lives in Yogyakarta and 109 lives in Central Java. Heavy damage was inflicted on 2,682 houses in Yogyakarta and 174 houses in Central Java, apart from the heavy disruption of livelihood facilities, roads, bridges, educational, health and public service facilities. ${ }^{2}$

The latter is mainly caused by human activities in terms of development process, such as increasing number of vehicle, massive build of hotels for tourism and lack of land use planning. ${ }^{3}$ It is also systematically effected by global warming as undeniable common phenomenon marked by several indicators, such as high rain drop rate in the rainy season between November and March, high heat in the hot season between April and October, and increasing bad quality of clean air whom all motor cycle driver use masker. When rain drop rate is high, water ponds spread along the City causing deadly dengue fever and diarrhea due to bad latrine system. When high heat strikes, body endurance drops causing physical illness such as influenza. Furthermore, bad quality of clean air decreases body endurance since it is prone to many respiratory illness and syndromes. As a

1 BPS, 2018, "Kota Yogyakarta Dalam Angka”, BPS Kota Yogyakarta; dan Indonesian Human development report 2001, Toward a new consensus; democracy and human development in Indonesia, BPS, Bappenas and UNDP, 2001.

2 BPS, 2017, Kota Yogyakarta dalam Angka, BPS Kota Yogyakarta, p. 1026.

3 PSPPR, 2009, Aglomarasi Perkotaan Yogyakarta, Laporan Kajian Aglomerasi Perkotaan Yogyakarta-Bapeda DIY, p. 11-20. 
result, human productivity is also affected especially for children who are enrolled to elementary and junior high schools. ${ }^{4}$ Furthermore, tension among residents has been increasing due to improper domestic waste management especially from private housing complex with local residents throughout Yogyakarta City.

The building blocks of climate resilience city are referred to as capital assets. It includes human capital (skills, knowledge, experience, and capacities), natural capital (natural resources such as water, land, forests, and minerals), physical capital (infrastructure, water and sanitation facilities, information and communication technology, housing, schools, health facilities, and other community and government structures), financial capital (such as savings, credit remittances, enterprise holdings, insurance, pensions, and livestock), political capital (access to and participation in decision making processes), and social capital (networks, group memberships, and social relationships). In crisis and post-crisis situations, tangible and intangible capital assets are easily lost, destroyed, or stolen. The capacity to preserve or recoup these capital assets determines the impact of a crisis on livelihoods of the society. ${ }^{5}$

Local Resilience Action Plan (LRAP) in Yogyakarta City attempts to bridge macro and micro level; emphasizing the importance of macro level policy and institutions to educate and disseminate communities and individuals on climate vulnerabilities and on their roles to cope with. It also stresses the need for higher level policy development and planning to be informed by lessons learnt and insights gained at the local level. This will simultaneously give local people a stake in policy and increase overall effectiveness. ${ }^{6}$ Much macro policy

4 See in general "The Right to Health", World Health Organization, http: / / www.who.int/mediacentre/factsheets/ fs $323 / \mathrm{en} /$, accessed on October 10, 2014 and United Nations High Commissioner for Human Rights, 2008b, The Right to Health: Fact Sheet Number 31, Office of the United Nations High Commissioner for Human Rights, Geneva, p. 27

5 GFDRR, 2014, Institutionalizing Post-Disaster Recovery: Learning from Mentawai Tsunami and Merapi Eruption, Conference Version; and Hennink, M.M. ,2007, International focus group research: A handbook for the health and social sciences. Cambridge University Press: Cambridge;

6 Maskrey, A., Module on Community-based Disaster Risk Management, CB- 
is developed in isolation from the people it affects. Indeed, understanding of the effects of policies on people (what actually happens as opposed to what is assumed will happen) and people on policies (the policy making process itself) are remarkably limited. Both these areas will need to be better understood if the full value of the CRC in the LRAP for communities in Yogyakarta City with slogan "City for All". ${ }^{7}$

The aforementioned vulnerabilities are worsened by imbalance waste management, contaminated water, lack of environment education and poverty. Consequently, CRC reveals imminent vulnerability of Yogyakarta City toward climate changes lies on community (care and aware) and how community empower themselves to actively participate in CRC process continuously. LRAP has been developed and has been taken into account for dissemination and for education involving all community institutions throughout Yogyakarta City.

This paper will discuss community participation for CRC as part of LRAP in the following order, first, it will outline community participation as fundamental framework for initiating and implementing CRC in the LRAP in Yogyakarta City. Second, it will critically examine community participation in the LRAP with special attribution to community institution role and function, e.g. Catholic Church to disseminate and to educate community to implement LRAP at the grass root level. Third, lesson learned of the implementation of the LRAP by community will be outlined to reveal strength and weakness for better and sustainable CRC in the future.

\section{B. Significance and Relevance of the Community Participation in the LRAP of the CRC}

Community participation is the heart of the implementation of the

DRM-2 Handout, Bangkok, (1998) and Mukherjee, A, 1995. Participatory Rural Appraisal; Methods and Application in Rural Planning, Vikas Publishing House PVT LTD.

7 Antara News, 2018, Yogyakarta Punya Kampung Iklim, ://jogja. antaranews.com/berita/355586/yogyakarta-punya-kampung-iklim, cccesed on Wednesday, 10 October 2018, 
CRC manifested in the LRAP in Yogyakarta in terms of dissemination and education to communities. ${ }^{8}$ It is a legal nomenclature creating certain legal rights and obligations in the Indonesian legal system since it is regulated in the Law on Disaster Management. Thus, community participation has been placed as the newest paradigm for conducting disaster management in Indonesia since 2007. ${ }^{9}$ It is understood as "a process in which at-risk community are actively engaged in the identification, analysis, treatment, monitoring and evaluation of disaster risk in order to reduce their vulnerabilities and enhance their capacities". As the newest paradigm, community participation tries to adjust internationally accepted paradigms with several consideration in Indonesia. ${ }^{10}$

First, Law 24 of 2007 directs active community role and function. It is compulsory to be taken by local governments since Indonesia is labeled as "supermarket" of disaster by the international community. Commonly, disaster is defined as "an occurrence of natural hazards impact on section of society causing death, injury, loss of property or economic losses that overwhelm society's ability to cope", ${ }^{11}$ from which the Law takes this significance in Article 1 (2). In this Article, tsunamis, earthquakes, floods, droughts, landslides and volcanic eruptions are literal examples for contextualizing this definition by emphasizing the fact that they "disrupt life of individuals, social interaction within society and living environments". ${ }^{12}$ As a result, active

8 Abarquez, Imelda and Murshed, (2005). Community-based Disaster Risk Management: Field Practitioners' Handbook, ADPC, p. 12-15.

9 Permana, R., (2007). Mengubah Paradigma Penanganan Bencana di Indonesia, Paper, West Java Disaster Reduction Studies Center, June 2007;

10 Asshiddiqqi, J., (2000). Otonomi Daerah dan Peluang Investasi, Paper on Government Conference on Peluang Investasi dan Otonomi Daerah, Jakarta, 30 September 2000; and Baiquni, M. and Rijanta, R., (2007). Konflik Pengelolaan Lingkungan dan Sumber Daya Dalam Era Otonomi dan Transisi Masyarakat, Paper (unpublished).

11 HIVOS, (2007). Disaster Management: Planning and Paradigm in Indonesia, 11 June 2007.

12 Hodgson., R.L.P., (1993). "Community Participation in Emergency Technical Assistance Programmes, “Technical Support for Refugees, (Proceedings of the 1991 Conference), ed, R.A. Reed, WEDC; and Hoffman, S.H., and Oliver-Smith, A., Catastrophe \& Culture, the Anthropology of Disaster, Ox- 
community participation has become a common terminology for massive campaign of mitigating, educating and preventing negative impact of disaster revealing issue of sustainable development plan in Indonesia. The Yogyakarta earthquake tragedy in 2006 supports this emphasis to which almost 6.000 people died and large scale of infrastructure damages. The paradigm aims to minimize communities' vulnerability and disaster risks throughout societies because they threaten the Indonesian development process (Preamble of the Law 24 of 2007). Although it has been accepted as a common terminology, many people do not have clear understanding on its substantial and on its practical uses due to its broad and full of technical meanings. Factually, those who bear predicate of marginalized groups such as urban communities do not aware of and do not take care of its contextual application in their daily life.

Secondly, deriving from the above definition, community participation is used exhaustively as a way, tool, method or steps to cope with by local communities in terms of reducing their vulnerabilities and of enhancing their capacities toward negative impacts of disaster events. In the Law 24 of 2007, the definition is adopted in Article 1 with special acknowledgement to performance and outcome indicators construed in the Hyogo Framework for Action 2005-2015 (The HFA, 2005), the ASEAN Agreement for Disaster Management and Emergency Assistance (ASEAN, 2006), and from the United Nations General Assembly Resolution 46/182 (UNGA, 2001). Community participation is "a process in which at-risk community to disaster are actively engaged in the identification, analysis, treatment, monitoring and evaluation of disaster risk in order to reduce their vulnerabilities and enhance their capacities".

Thirdly, the Law substantially regulates active participation from community institutions by initiating community based resources management system principle as the core or legal ethical principle under Article 3, i.e. justice, humanity, balance and harmony. The fact that this principle is construed extensively in almost sections in

ford. 
this Law make it worth to be analyzed from legal and from political point of views. Although there are no official explanations for this legal stance, Government intentionally wants to apply the concept of the human rights based-approach for all efforts to enhancing capacity building of the community by empowering them as the subject nor as the objects. ${ }^{13}$ First, communities' involvement is manifested to community level initiatives for disaster risk reduction. Secondly, role of vulnerable groups and persons is central point of view since it is about their life. Lastly, nobody can understand local opportunities and constraints better than themselves. These rationales are believed to be deductively relevant with the changing patterns of disaster occurrence and loss resulting from natural hazards and from the application of the good governance principle in the political decentralization system in Indonesia. ${ }^{14}$

Fourth, the motivation to attribute the principle is also worthy to note as another framework of analysis to implement CRC in the LRAP in Yogyakarta City. It is substantially derived from the Indonesia' ratification toward international human rights law instruments. They are, for examples, the International Covenant on Economic, Social and Cultural Rights (ICESCR) ratified on September 12, 2005 by the Law 11 of 2005, and the United Nations Frameworks Convention on Climate Change (UNFCC) ratified by Act 17 of 2004 at grass root level. Thus, in this legal construction, it is believed that the adoption of this principle is intended to show Government's willingness and its capacity to progressively achieve the economic, social and cultural rights to its people in development process. ${ }^{15}$

Fifth, the existence of the Law 26 of 2007 regarding the Spatial Planning Program plays its significance because it was issued to further consolidate the management of natural resources sustaining development. This Law acknowledges the importance of community

13 BNPB, UNDP, 2013, Merapi; Pemulihan Penghidupan Warga Pasca Letusan 2010 (Laporan Survei Longitudinal).

14 Regnier, P. et. al. , 2008, From Emergency Relief to Livelihood recovery; Lesson Learned from Post Tsunami Experiences in Indonesia and India.

15 Tomasevski., K., (1995). "Indicators", in ”, in Asbjorn Eide (et.all), Economic, Social and Cultural Rights, A Textbook, p. 25. 
participation when they build and use the land. In this regard, the Law determines that the type of local environmental governments is the most appropriate model of governance to sustain development. This Law determines detail technical and procedural planning carried out by governments. It targets into more accountable and more transparent assessment of the progress of the spatial planning program to be conducted by all local governments. ${ }^{16}$ In simple terms, the spirit of the Law requires a clear, robust, just and accountable spatial planning program of management of natural resources implemented by all local governments. As the natural disaster risks are essentially local, their impacts will be directly experienced by communities. This Law in principle governs the participatory disaster risk assessment, community-based natural disaster risk management planning, community managed implementation and monitoring and evaluation as the essence of LRAP in the CRC in Yogyakarta City.

Seventh, the application of the theory of breakdown of natural resources management proposed by Jacqueline ${ }^{17}$ is truly adopted as the main logical framework for making local spatial planning program. This theory opens chance that "decentralized natural resources management system by smaller units (local governments and communities) will increase opportunity of participation from multi stakeholders, increase roles of civil society and open up intensive interaction among stakeholders for the natural resources management at local levels" ${ }^{18}$ In simple terms, this theory reveals that those who have biggest interests will have the biggest access to management and to enjoyment of natural resources viewed from the spatial planning program. ${ }^{19}$ Arguably this concept plays its role as the ultimate

16 Eman, R., (2008). "Sosialisasi Peraturan Pemerintah tentang Pelaksanaan Penataan Ruang”, Workshop Paper on Disemination on Spatial Planning, Gadjah Mada University, 17 September 2008

17 Jacqueline, A., (2008). Alternative Approaches to Managing Conflict in the Use of Natural Resources, Presentation Material on International Workshop on Natural resources Management, Washington D.C., May 2008;

18 Ibid.

19 Ribot, J.C., (1990). Accountable Representation and Power Participation and Decentralized Environmental Management, Unasylva 1999, Volume 50, p. 13. 
condition to achieve the community participation for implementation of the CRC in the LRAP in Yogyakarta City.

The essence and significance of all laws and policies above underlines relevance, efficiency, effectiveness, sustainability and impacts for community participation in the CRC in Yogyakarta City construed in the LRAP in terms of dissemination and education of sustainable environmental development. ${ }^{20}$ Education and dissemination of imminent vulnerabilities in Yogyakarta and how to cope with are revealed by asking prominent questions: first, relevance on how consistent the intended outputs of community participation in the CRC adopted in the LRAP aligned with national and local policies and priorities and the needs of the governments in Yogyakarta. In what extent the planning, design and implementation of community participation will be able to respond to changing and emerging priorities and needs following the disasters caused by climate change in Yogyakarta City in a responsive manner? Second, appropriateness on how is the cultural (acceptability and adaptability) acceptance toward the method of delivery carried out by community institutions? Whether the initiative operationalized is acceptable and feasible within the local context? Third, effectiveness in terms of whether the intended results of community participation in CRC have been achieved? What is the change that happen at output or outcome level? What is the initiative or determining participation toward observed changes? Fourth, efficiency on how economically resources or inputs (such as funds, expertise and time) were converted to results of resilience community in Yogyakarta? Whether the resources have been used appropriately and effectively? Fourth, sustainability on how is the capacity of the government to maintain, manage and ensure the results of CRC in future? What kind of sustainability strategy has been developed and/or implemented in Yogyakarta City? Whether financial mechanisms are in place to ensure ongoing benefits? Whether policy and

20 ASEAN Disaster Preparedness Center, (2006). Community-Based Disaster Risk Management, Bangkok; and ASEAN Agreement on Disaster Management and Emergency Response, (2008). http:/ / www.aseansec.org/ 17579. htm, accessed on June 2nd; 
regulatory frameworks are in place to ensure the continuation of the result? Fifth, impact on what kind of changes in human development and people's well beings that are brought about by the LRAP within the scheme of the CRC in Yogyakarta City, directly or indirectly, intended or unintended?

Related to the implementation, efficiency and effectiveness require local government (Mayor of the Yogyakarta City) to enact for example a plan of action adopting detailed concrete norms setting and institutionalization for progressive, locally attainable, and contextual for minimizing vulnerability as well as hazards in the affected regions and to the victims. The programs undeniably help to structure local policies on disaster management in the future. Viewed from the norm settings in the CRC, the implementation of the programs among the regions help local governments of Yogyakarta City improve their capacities to manage disaster as part of its local development plans to disseminate and to educate affected communities. At the end, results in form of the establishment of policies a per local needs; identification and prioritization most vulnerable communities; conducting local risk assessment; supporting development of local documents for coping mechanism and expertise; establishment of Early warning System (EWS); upgrading disaster preparedness, mitigation plan and support for resources are obtained as indicator for effectiveness and efficiency. All these phases are regulated in the Mayor Regulation of Yogyakarta City 3 of 2011 regarding Local Disaster Management.

In provincial level, there are at least 8 initiations of local government regulations resulted from disaster management highlighting importance of the CRC in Yogyakarta City. Four have been entry into force while others are still discussed with local House of Representatives. In general, all are inspired by "Merapi Mystery", notions devoted to cope with imminent natural hazards. It becomes a new concept on how to cope with future imminent threats (hazard and risk) since its potential eruption heads to the south (Yogyakarta). ${ }^{21}$

21 Eddy Permana, 2013, Head of the Cangkringan Village, Interview. 
Alongside Malioboro Street and Kali Kuning river, sister village information system has been accepted as one of the most important norms setting for active community participation. Sister village information system has become major achievement in terms of the establishment of the EWS from imminent threat of Merapi Eruption in the future connecting communities between Sleman regency, Yogyakarta City and Bantul Regency. From the programs, there are successful pilot projects in Cangkringan, and in Glagah, Sleman regency and in Taman Agung and Srumbung villages copied by Jetis Harjo, Karangwaru, Gondokusuman and Mantrijeron sub regency in Yogyakarta City.

Viewed from the local development policies, the accessibility and the availability of correct information of the regions, true participation from community living in the regions and planning for reaching equal benefits among stakeholders are indicators for effective creation of spatial planning for land and water usages as pre-requisite for appropriate management of resources by community level. Following this method, the availability and the accessibility indicators place local governments to play the role of a facilitator, enabler and resource provider in order to promote community level risk reduction and preparedness in the implementation of the programs into two basic obligations. First, local governments have to provide technical assistance. Lastly, local governments should allocate funds to families and communities groups for disaster risk reduction, preparedness and responses. ${ }^{22}$ Furthermore, institutionalization of village disaster task force with coordinator of the head of sub districts in Yogyakarta City is one of relevant example. Simplification of procedure and coordination among duty bearers such as local disaster management bodies (BPBD Kota and Provinsi) with villages (community) form a distinguish mechanism for better management of imminent threat of the "Merapi Mystery" in the future sustaining acceptability of the affected communities of the CRC initiatives since 2010.

In order to meet the objective and key areas concerned above,

22 Maskrey, A., (1998). Module on Community-based Disaster Risk Management, CBDRM-2 Handout, Bangkok, p. 24. 
LRAP in the CRC of Yogyakarta City used Sustainable Livelihood Framework ${ }^{23}$ to guide the evaluation process in terms of dissemination and education. The framework is a versatile tool for development project planning and management. It offers a way of thinking about livelihoods that helps order complexity and makes clear the many factors that affect livelihoods including its risk of climate changes. The sustainable livelihoods framework presents the main factors that affect people's livelihoods, and typical relationships between these. In particular, the framework provides a checklist of important issues and sketches out the way these link to each other; draws attention to core influences and processes; and emphasizes the multiple interactions between the various factors which affect livelihoods of the affected communities in Yogyakarta City. Using the framework, the evaluation captured the change that took place before and after the intervention through the LRAP in the CRC between 2010 and 2018. To overview how the inputs, capacity building, and assistance that being provided by CRC gives impact to the community.

Livelihoods approach regard human as the most important element. The approach tries to gain accurate and realistic understanding of human strength (assets and capital) and how human work hard to change asset and capital into positive results of their livelihood which prone to climate changes. This approach is based on the belief that human needs variety of assets to produce positive results of their livelihood and living surrounding. The evaluation process underlined the relation between the type of program interventions such as household waste management, green life style, drainage, new plantation and latrine system and then looking forward on how those interventions influence the affected community in Yogyakarta City. ${ }^{24}$ Change of mindset and impact of regulation or policy took place during the intervention can be assessed in terms of education and dissemination conducted by community institutions in Yogyakarta City between 2010 and 2018. 


\section{Dissemination and Education of CRC in the LRAP by Community Institutions}

In performing activities related to strengthening village disaster response to climate changes, LRAP took the regulation of BNPB Number 1/2012 on Resilient Villages as reference for conducting the CRC in Yogyakarta City. The regulation stipulates that there are 12 requirements that should be met in order to establish a "Resilient Village" in order to achieve broader resilience city. However, only 9 out of the 12 requirements mentioned in BNPB Regulation were adopted by LRAP. The 9 requirements are: (1) availability of community hazards maps; (2) availability of community vulnerability maps; (3) availability of community capacity and resource maps; (4) availability of Village Disaster Management (DM) Plans; (5) availability of Village Action Plans on DRR; (6) availability of Village Disaster Management Teams (VDRRTs) and Village Disaster Risk Reduction Forums (VDRRF); (7) availability of Community-Early Warning Systems (EWS); (8) availability of Village Contingency Plans (Including Evacuation Plan); and (9) the implementation of the Economic Resilient activities. Dissemination of community's vulnerabilities due to climate changes and education on how to cope with such vulnerability have been introduced in the CRC and LRAP schemes. ${ }^{25}$

This serial of intervention has increased the capacity of community to cope with disaster risks around them. The LRAP program was implemented simultaneously by local government of Yogyakarta, universities, NGOs and community institutions, i.e. village level community and functional institutions, such as religious institutions, for examples Catholic Church, Youth Mosque Movement and Mother Associations in every village levels which designed three activities: providing trainings, coaching (technical assistance), and expanding

25 Pace, Paola, 2009. Migration and the Right to Health: A Review of International Law. International Organization for Migration Publication. Geneva; and Pietropaolo, Maria Giovanna, 2013. Humanitarian Assistance from the Standpoint of the Human Rights of the Disaster-Affected Individuals: Present and Future Perspectives. Geneva Academy of International Humanitarian and Human Rights. Geneva. 
market access for waste recycle management. The beneficiaries of these activities are those who own business for waste recycle management and traders for harvesting fruits and daily consumption. Businessman and traders have also encouraged the beneficiaries to apply for Home Industry Product license.

The focus of the activities to strengthen village resilience teams is the establishment of the contingency plan at the sub-village level. The sub-village level was chosen based on the previous experience when such contingency plan was established at the village level, which makes only a small number of village elites who have proper knowledge about the contingency plan. Consequently, when flood and high heat took place, the response from the community was somehow as expected. Local Disaster Management Body (BPBD Kota) also cooperated with local Disaster Risk Reduction Community (DRRC). DRRCs were also involved in disaster risk reduction management in dissemination and education for climate changes under the LRAP. There were two documents that have been issued from this activity. The first one is community early warning system at the sub-village level, and the other is the Contingency Plan at the village level which covers more detailed plan at sub-village level.

Community intense participation for implementing the LRAP for CRC in Yogyakarta City is probably best reflected by the Catholic Church for its active and meaningful participation to educating and disseminating climate changes to its congregation. The new world can be a very helpful place for the Church, but it doesn't mean that there's no challenge and obstacles along the journey to adjust to the new world marked by climate change. The challenges of the times seem to make the values put forward by the Catholic Church increasingly submerged by the power of business and material interests, especially in Yogyakarta City as part of great archbishop of Semarang. Nowadays, in various churches, people are increasingly-active in participating in liturgical celebrations highlighting for achievement of passion-based community of $2035 .{ }^{26}$ Passion-based community is an

26 RIKAS 2015, Rencana Induk Keuskupan Agung Semarang, KAS, p. 15-27. 
internal-driven services devoted by Catholic Church in order to respecting God creation of environment as human beings are placed as pivot to their living surroundings. ${ }^{27}$

Modern life is characterized by automatism of information technology which information on Church policy of respecting God creation is well managed to improve community care and awareness. Many things are easily carried out automatically: at home, in the office, traffic, shopping centers, recreation areas, and others. It could be that this automatic attitude affects us when celebrating liturgy. This raises doubts and thoughts that, we are also (only) automatically carrying out the obligation on Sunday, join in reciting prayers that have even been memorized, singing songs that are familiar -as long they are in good melodies and not caring about the meaning of the lyrics. All the people knelt, stood up and bowed, so we followed along too as part of routine celebration. However, since 2015, Catholic Churches in Yogyakarta City has improved this routine celebrations to contextualize human interaction and human communication in order to actively engage community commitment on minimizing vulnerability of natural and man-made hazards by educating children and youngsters to environment in Sunday Schools and functional Church social activities, such as increasing budget allocation to those in needs.

But of course, when Church is not superficial in making use of all the progress that exists and the way of life in this new world, where everything is fast and hasty (which was later labeled as the hallmark of modern-secular society), the new modern world can be really helpful in order to spread the Religion and kindness. It is interesting to note that the identity of the church is no longer seen as an institutional organization merely, but as a partnership that is a way of relating which is characterized by sharing of life and communication. In the context of evangelism, all media can be used by the church in a depth that involves conscience and morality to environmental devotion. All of this is in the spirit of admiration and gratitude for the generosity that God has bestowed upon human beings to be able to 
find those means. There are seven Catholic Church administrations in Yogyakarta City administering more or less 43.453 people. ${ }^{28}$ They are illustrated below describing their indirect contribution to LRAP on CRC in Yogyakarta City.

First, Saint Mary Immaculate Catholic Church/Gereja Santa Maria Tak Bercela Kemetiran. This church is located at Jl. Kemetiran Lor No.13, Pringgokusuman, Gedong Tengen, Kota Yogyakarta, Daerah Istimewa Yogyakarta 55272. The Church grows in a densely populated area but diverse residential areas that prone with poverty and poor sanitation and drainages. The people come from different backgrounds, economic abilities, race, even age, with majority of the inhabitant come from middle class incomes. In order to develop a balanced manner for the Church's life, the quantitative development of the people has been accompanied by an increase in the quality of life of faith for internal belief to respect environment. One of the quality of life of faith is to pay attention to those who are underprivileged or even marginalized. The Church then established "dana sehat" (healthy fund in English) for public health services and for social activities there are a Health Clinic, Pangrukti Laya, Pralenan Funds are well designed and distributed to its congregation. Health clinics are used by congregations and local people in need. The Church also invited laypeople who work in the RT / RW (local government) level to carry out the task as a public service call to embody what Christ and Catholic taught us, to be the salt and light of the world with encouraging establishment of waste management system and adding water reservoir since 2015. Even if this Church location is (relatively) near the most favorite tourist attraction in Yogyakarta, the Malioboro Street, with the bustling nightlife, this Church still maintains its existence and the way it creates a high-social environment. The threat doesn't come in a physical form, but in mental and moral form deterioration due to massive influence of tourist industry in this region.

Second, Church of St. Francis Xavier / Gereja Santo Francis-

28 BPS Kota Yogyakarta, 2018, Kota Yogyakarta dalam Angka, BPS Kota Yogyakarta. 
cus Xaverius Kidul Loji. It is located at Jl. Panembahan Senopati No.22, Prawirodirjan, Gondomanan, Yogyakarta. Known as the oldest church in the city, its location is located in the heart of the city, nearby the Keraton Palace and Alun-alun or the Palace Square. Even the church itself is located behind a large parking lot, that's full with buses that come from various regions making the Church as a place for Catholic pilgrims who are visiting Yogyakarta City. Sometimes, it makes Kidul Loji Church somehow become a tourist attraction, a place for them who are curious about the oldest church in the city. Its location, that's in the middle of the crowd is even considered as the most crowded spot in the city- sometimes makes the atmosphere around the Church not solemn. Even if it's a good thing that people want to know and see the Church, in fact the number of people passing by is a threat to the Church. The threat that this Church receive come from many foreign people around it, the easy access around the Church and into the Church, makes this Church vulnerable enough to interference from irresponsible parties who wanted to spread hatred. Realizing this imminent threats of social interaction, the Council of the Church has developed good mutual understanding with community to safeguard its existence. This kind of mutual understanding creates better social networking where education and dissemination of negative impacts for bad quality of air has been their common problems. Increasing green plantation in each sub village and household area has been major achievement of this Church to the community and vice versa.

Third, Church of St Anthony of Padua / Gereja Santo Antonius de Padua Kotabaru. It is located at Jl. Abu Bakar Ali No.1, Kotabaru, Gondokusuman, Kota Yogyakarta, Daerah Istimewa Yogyakarta 55224. This Church is the most well-known church in DIY Province. Built during the Dutch colonial era, by the Dutch people themselves, with the permission and help from Sri Sultan HB VII as the ruler of the Province. This church stands majestically in the middle of a residential area. Some features indicate that this church imitates the style of the church in Europe. At present, Kotabaru is one of the cultural heritage areas, the old-fashioned and classic buildings must 
be maintained. This Church is the most favorite for young people; teenagers, students, young family. In simple terms, Kotabaru Church is the millennial Church example in the City. Due to its location and the large number of people, escort from the police and security in the Kotabaru Church is the biggest compared to the other churches, because the threat has been even greater. On big days like Easter and Christmas, there are security check from the police, checking people's bags in case someone carrying dangerous goods. Millennial lifestyle has been used by the Church Council to educate and disseminate climate changes in Yogyakarta City by reducing and limiting $\mathrm{CO} 2$ release when its congregation come to the Church. Limitation of parking lots has been successfully educate and reduce numbers of vehicles using IT and social media.

Fourth, Church of Christ the King / Gereja Kristus Raja Baciro. It is Located at Jl. Melati Wetan No.47, Baciro, Gondokusuman, Kota Yogyakarta, Daerah Istimewa Yogyakarta 55225, Indonesia. This church is located near the Yogyakarta Mayor's Office, causing many securities guarding the church when a Mass is held, especially on big days. The Baciro Church is famous for its faith education services to children. Children are really loved by Jesus, they are His favorites and early environmental education has been successfully given to children with easy and robust environmental syllabus and examples of loving activities to environments. They are still innocent, sacred, and sincere, like blank canvas, so that they can still be filled with kindness and virtue of environmental and behavior of love to environment. That is why the cultivation of values for children is one of the main focuses for the Church. Being in the middle of a school environment, residential homes, and close to the Government Offices and Military Headquarters, makes this Church quite protected but also quite threatened at the same time. The existence of the Church accommodates Catholics from various circles and levels of society, making the Baciro Church grow as a place for strategic, appropriate and cultured socialization where appropriate drainages and green plantations have been appropriately built and safeguarded by active role of the society. 
Fifth, Church of Saint Joseph / Gereja Santo Yusuf Bintaran. It is located at Jl. Bintaran Kidul No.5, Wirogunan, Mergangsan, Wirogunan, Mergangsan, Kota Yogyakarta, Daerah Istimewa Yogyakarta 55151, Indonesia. Bintaran Church is the first Javanese Church dedicated and built for Javanese and indigenous people with a unique and distinctive forms of Javanese culture. There are almost no similar buildings in Indonesia and, there are only one similar building that's located in the Netherlands as the parent of his church. At present the existence of the Church of St. Jusuf is on the list of Cultural Heritage. The Bintaran Church has long been known to be active with a variety of social activities, one of which had succeeded in gathering the trans migrants' departure to Lampung, Sumatra, where the transit site also took place in the Church Hall. Education and dissemination of continuous land cultivation to those trans migrant workers has been major achievement of this Church participation for environmental educations.

Sixth, Church of Saint Albertus Magnus / Gereja Santo Albertus Magnus Jetis. It is located at Jl. AM. Sangaji No.20, Cokrodiningratan, Jetis, Kota Yogyakarta, Daerah Istimewa Yogyakarta 55233. In empowering the people at Jetis Church, there are several social actions that have been carried out. Among other things, during the Church's birthday, a free health check was held, turning on the Parish library, donating assistance to the sick, providing financial assistance for grieving people and providing tuition assistance to disadvantaged children. Furthermore, regarding the empowerment of the people's economy is carried out through the Social Economic Development Working Team. Economic empowerment for the people is mainly to help the economies of the poor, such as borrowing money as business capital where loan funds are not subject to interests. In this Church, commitment to environmental education and dissemination have become its distinct values where every year there is environmental competition held by the Church to increase public participation to minimize community vulnerability of high heats by gardening the Church with real flowers and plantations. Each community levels has to manage and decorate Church with those living plantations every 
weeks promoting green and healthy lifestyles to its congregation where this Church manages 19 villages. ${ }^{29}$

Seventh, Church of the Sacred Heart of Jesus / Gereja Hati Kudus Tuhan Yesus Pugeran. It is Located at Jl. Suryaden No.63, Suryodiningratan, Mantrijeron, Kota Yogyakarta, Daerah Istimewa Yogyakarta 55142. In the past, Pugeran Church was able to be a part of the locality of the surrounding community by directly acting as part of the media to maintain Indonesian independence and become a forum for communication from political and social upheavals in that time. Pugeran Church also interferes with culture, for instance there's a mass held in Javanese language, and we'll see many elderly wearing traditional Javanese clothes during the mass because of its location that's in the middle of a long-standing residential house. The church stands right on the edge of the main highway, in the southern area of Yogyakarta City. Although this Church can be said to be far enough from any threat, it is not uncommon to find a number of police and security guards who guard around the Church.

It's a common thing here in this city, that there's a Private Catholic School built near every church. For instance, Kanisius Baciro Elementary School (ES) and Joannes Bosco JHS right beside Baciro Church, Pangudi Luhur SHS beside Kidul Loji Church, there's Stella Duce 1 JHS near Kemetiran Church, Bopkri Bintaran ES near Bintaran Church, Kanisius Pugeran ES and Stella Duce 2 SHS near Pugeran Church, Stella Duce 1 SHS and Kanisius Kotabaru ES near Kotabaru Church. It isn't something that's unintentional, there's a purpose, namely creating a generation of Catholics who obey to instill religious values in daily life, starting with the smallest thing that is in school. There are Masses / Eucharist held regularly in these schools, for instance Easter Mass, mass before examinations, school birthdays, because of its location to the Church, to make it easier for both the school and the Priest, and to increase the students' solemnness, Mass is held in the Church.

The Catholics in Yogyakarta is very susceptible to discordance,

29 Joko Sunarno, 2018, Head of the Environmental Competition of St. Albertus Agung Church, Yogyakarta, Interview. 
terror, and threats. There are several churches that have received threats in various forms, such as bombs, swords, or just pure fear. That is the reason why, if we really pay attention, there are always police and securities who guard the church during the mass, particularly on big events like Christmas and Easter. That thing on the other hand, make them vulnerable to "religious pride". They always see the other religion as a spreader of terror and evil deeds. It makes them proud of their own religion, and shapes them into individualistic people that have a narrow mind, an ugly way of thinking. For instance, if there is any terror or oppression, no matter how light that is, they tend to blame other religions. Whereas a terror and threat may not come from someone who has religion and faith, it comes from irresponsible parties who have no religion and know no God. But they (Catholics) cannot be blamed, that is what you will feel when you experience and receive pressure and threats from various parties on a regular basis.

The young Catholics also organizes a number of events for the public, such as workshops with the theme of corruption, the environment and other social issues. Muslim teenagers are involved as volunteers who will talk about Islam in Indonesia. The Youth Catholic's encounter with young Muslim colleagues is expected to be a space for mutual understanding of Islam and harmony in life as young people in Indonesia. The whole social actions thing is an important matter, especially in this new modern world where everything can be a threat, everyone can be suspect, and every person can be victim. Where hatred and defamation can be easily spread by the technology, Catholic Church in Yogyakarta City have been actively engaged to environmental education and dissemination with their own belief and internal driven motivation far from formal intervention of the governments. It reflects the importance of day to day activities of care and aware of deterioration of the environment by doing small things but in turn reaching big things as the heart of the LRAP for achieving Yogyakarta City as role model of the Climate Resilience City in Indonesia. 


\section{Conclusions}

This paper reveals two conclusions. First, since 2012, Catholic Churches and Islamic Youth organization in Yogyakarta city have played role to educate and to disseminate CRC through their internal Church guidance of the arch Bishop of Semarang manifestation 2035 and trough speech from Islamic leaders, e.g. participation to sustainable changes through community active participation on their daily life. Secondly, internal driven motivation that taking care of environment is one of fundamental Christian values has been effective to continuously manage house hold wastes, increase green Catholic life style, and to map potential climate vulnerabilities in all 7 churches administration, such as community early warning of flood, earth quake and drought. Similarly, Islamic Youth Organizations also support this awareness although it is rather difficult to find out such guidance. Empowerment of local community is best practice to continuously sustain international obligations under the UNFCC and the Paris Agreement manifested in their day to day activities that is far from forceful intervention of the Government. In general, this paper concludes that CRC is a process. As a process, it places local governments as resources providers, facilitator and enabler for conducting policies, programs, actions and funds in a very formal way of intervention for conducting CRC. On the other hand, community participation has been effective in terms of education and dissemination of danger of climate change due to their informal and pure motivation built by religious or internal driven beliefs. Consequently, CRC has to be directed into more attention to community participation where policy, programs, actions and funds follow community needs and initiatives, rather local government initiates them with less attention them.

\section{Bibliography}

"The Right to Health", World Health Organization, http://www.who. int/mediacentre/factsheets/ fs $323 / \mathrm{en} /$, accessed on October 10, 2014 and United Nations High Commissioner for Human Rights, 2008b, The Right to Health: Fact Sheet Number 31, Office 
of the United Nations High Commissioner for Human Rights, Geneva;

Abarquez, Imelda and Murshed, (2005). Community-based Disaster Risk Management: Field Practitioners' Handbook, ADPC;

Antara News, 2018, Yogyakarta Punya Kampung Iklim, ://jogja. antaranews.com/berita/355586/ yogyakarta-punya-kampungiklim, cccesed on Wednesday, 10 October 2018;

ASEAN Disaster Preparedness Center, (2006). Community-Based Disaster Risk Management, Bangkok; and ASEAN Agreement on Disaster Management and Emergency Response, (2008). http: / / www.aseansec.org/ 17579.htm, accessed on June 2nd;

Asshiddiqqi, J., (2000). Otonomi Daerah dan Peluang Investasi, Paper on Government Conference on Peluang Investasi dan Otonomi Daerah, Jakarta, 30 September 2000;

Baiquni, M. and Rijanta, R., (2007). Konflik Pengelolaan Lingkungan dan Sumber Daya Dalam Era Otonomi dan Transisi Masyarakat, Paper (unpublished);

BNPB, UNDP, 2013, Merapi; Pemulihan Penghidupan Warga Pasca Letusan 2010 (Laporan Survei Longitudinal);

BPS Kota Yogyakarta, 2018, Kota Yogyakarta dalam Angka, BPS Kota Yogyakarta;

BPS, 2017, Kota Yogyakarta dalam Angka, BPS Kota Yogyakarta;

BPS, 2018, "Kota Yogyakarta Dalam Angka”, BPS Kota Yogyakarta; dan Indonesian Human development report 2001, Toward a new consensus; democracy and human development in Indonesia, BPS, Bappenas and UNDP, 2001;

Eddy Permana, 2013, Head of the Cangkringan Village, Interview; Eman, R., (2008). "Sosialisasi Peraturan Pemerintah tentang Pelaksanaan Penataan Ruang”, Workshop Paper on Disemination on Spatial Planning, Gadjah Mada University, 17 September 2008;

GFDRR, 2014, Institutionalizing Post-Disaster Recovery: Learning from Mentawai Tsunami and Merapi Eruption, Conference Version; and Hennink, M.M. ,2007, International focus group research: A handbook for the health and social sciences. Cambridge University Press: Cambridge; 
HIVOS, (2007). Disaster Management: Planning and Paradigm in Indonesia, 11 June 2007;

Hodgson., R.L.P., (1993). "Community Participation in Emergency Technical Assistance Programmes, "Technical Support for Refugees, (Proceedings of the 1991 Conference), ed, R.A. Reed, WEDC;

Hoffman, S.H., and Oliver-Smith, A., Catastrophe \& Culture, the Anthropology of Disaster, Oxford;

Irwanda Wredaningrum, 2015, Analisis Perubahan Agroklimat Dearah Istimewa Yogyakarta ditinjau dari Klasfikasi Iklim Menurut Oldeman, Paper, Unpublished;

Jacqueline, A., (2008). Alternative Approaches to Managing Conflict in the Use of Natural Resources, Presentation Material on International Workshop on Natural resources Management, Washington D.C., May 2008;

Joko Sunarno, 2018, Head of the Environmental Competition of St. Albertus Agung Church, Yogyakarta;

Maskrey, A., (1998). Module on Community-based Disaster Risk Management, CBDRM-2 Handout, Bangkok, p. 24.

Maskrey, A., Module on Community-based Disaster Risk Management, CBDRM-2 Handout, Bangkok, (1998) and Mukherjee, A, 1995. Participatory Rural Appraisal; Methods and Application in Rural Planning, Vikas Publishing House PVT LTD;

Pace, Paola, 2009. Migration and the Right to Health: A Review of International Law. International Organization for Migration Publication. Geneva; and Pietropaolo, Maria Giovanna, 2013. Humanitarian Assistance from the Standpoint of the Human Rights of the Disaster-Affected Individuals: Present and Future Perspectives. Geneva Academy of International Humanitarian and Human Rights. Geneva;

Permana, R., (2007). Mengubah Paradigma Penanganan Bencana di Indonesia, Paper, West Java Disaster Reduction Studies Center, June 2007;

Petersmann, E., (1993). "Legal, Economic and Political Objectives of National and International Competition Policies: Constitutional 
Functions of WTO "Linking Principles" for Trade and Competition", 34 New England Law Review;

Petersmann, E., (1996). "Constitutionalism and International Organization”, 17 Northwestern Journal of International Business;

Petersmann, E., (1999). "How to Constitutionalize International Law and Foreign Policy for the Benefit of Civil Society?”, 20 Michigan Journal of International Law;

Petersmann., E., (2001). "Human Rights and International Economic Law in the $21^{\text {st }}$ Century: The Need to Clarify Their Interrelationship", 4 Journal of International Economic Law;

PSPPR, 2009, Aglomarasi Perkotaan Yogyakarta, Laporan Kajian Aglomerasi Perkotaan Yogyakarta-Bapeda DIY;

Regnier, P. et. al. , 2008, From Emergency Relief to Livelihood recovery; Lesson Learned from Post Tsunami Experiences in Indonesia and India;

Ribot, J.C., (1990). Accountable Representation and Power Participation and Decentralized Environmental Management, Unasylva 1999, Volume 50;

RIKAS 2015, Rencana Induk Keuskupan Agung Semarang, KAS;

Yoseph Sumartono and Fred Mujiharto, 2018, Interview; 